\title{
DISSOLUTION OF DIATOM FRUSTULES AND SILICON CYCLING IN
}

LAKE MICHIGAN, U.S.A.

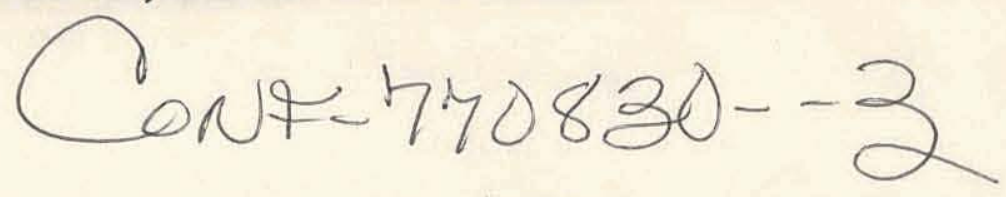

J. I. Parker, H. L. Conway, E. M. Yaguchi, and D. N. Edgington

Prepared for

20th Congress of the International Association of Theoretical and Applied Limnology Copenhagen, Denmark

August 7-14, 1977
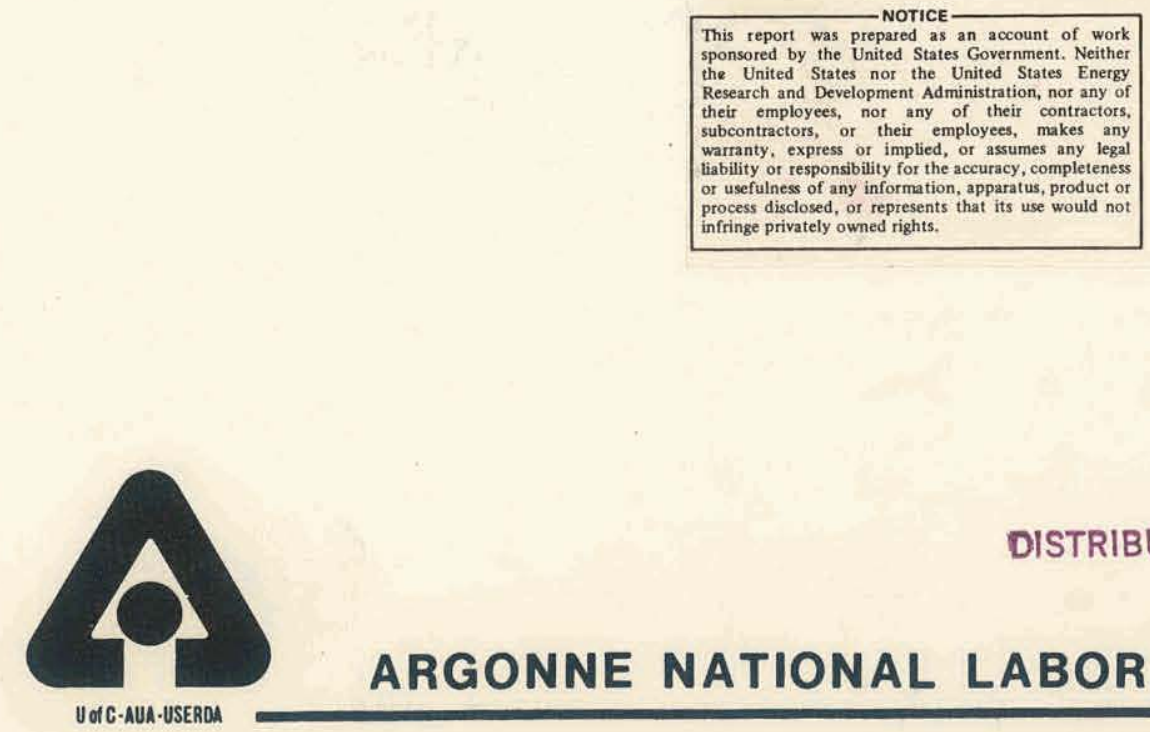


\section{DISCLAIMER}

This report was prepared as an account of work sponsored by an agency of the United States Government. Neither the United States Government nor any agency Thereof, nor any of their employees, makes any warranty, express or implied, or assumes any legal liability or responsibility for the accuracy, completeness, or usefulness of any information, apparatus, product, or process disclosed, or represents that its use would not infringe privately owned rights. Reference herein to any specific commercial product, process, or service by trade name, trademark, manufacturer, or otherwise does not necessarily constitute or imply its endorsement, recommendation, or favoring by the United States Government or any agency thereof. The views and opinions of authors expressed herein do not necessarily state or reflect those of the United States Government or any agency thereof. 


\section{DISCLAIMER}

Portions of this document may be illegible in electronic image products. Images are produced from the best available original document. 
The facilities of Argonne National Laboratory are owned by the United States Government. Under the terms of a contract (W-31-109-Eng-38) between the U. S. Energy Research and Development Administration, Argonne Universities Association and The University of Chicago, the University employs the staff and operates the Laboratory in accordance with policies and programs formulated, approved and reviewed by the Association.

\section{MEMBERS OF ARGONNE UNIVERSITIES ASSOCIATION}

The University of Arizona

Carnegie-Mellon University

Case Western Reserve University

The University of Chicago

University of Cincinnati

Illinois Institute of Technology

University of Illinois

Indiana University

Iowa State University

The University of Iowa
Kansas State University The University of Kansas Loyola University Marquette University Michigan State University The University of Michigan University of Minnesota University of Missouri Northwestern University University of Notre Dame
The Ohio State University

Ohio University

The Pennsylvania State University

Purdue University

Saint Louis University

Southern Illinois University

The University of Texas at Austin

Washington University

Wayne State University

The University of Wisconsin

NOTICE

This report was prepared as an account of work sponsored by the United States Government. Neither the United States nor the United States Energy Research and Development Administration, nor any of their employees, nor any of their contractors, subcontractors, or their employees, makes any warranty, express or implied, or assumes any legal liability or responsibility for the accuracy, completeness or usefulness of any information, apparatus, product or process disclosed, or represents that its use would not infringe privately-owned rights. Mention of commercial products, their manufacturers, or their suppliers in this publication does not imply or connote approval or disapproval of the product by Argonne National Laboratory or the U. S. Energy Research and Development Administration. 


\section{Introduction}

Diatoms require dissolved silicon for the formation of the silicate frustule that surrounds the cell. Potential sources of this silicon include dissolution of frustules produced by previous diatom communities, inputs of dissolved silicon from land drainage, and dissolution of silicate minerals. Frey (1974) suggested that very little silicon is recycled from. dissolution of frustules in Belham Tarn, U.K., and that diatom production probably depends on land drainage inputs. However, greater than $50 \%$ of the sedimentary diatoms were dissolved and recycled in Lough Neagh, U.K. (Battarbee, 1972). In the Laurentian Great Lakes, Duthie and Sreenivasa (1971) described a paucity of diatom frustules in the sediment, suggesting that much of the silicon is recycled before the silicate frustules are permanently buried in the sediment. Although these observations indicate the importance of specific silicon sources in lakes, our general knowledge of the sources, sinks, and biogeochemical behavior of silicon in aquatic ecosystems is poor.:

We investigated the relationship between diatom-frustule production, sedimentation and dissolution to determine the importance and the mechanisms of silicon recycling in a large temperate lake, Lake Michigan.

\section{Methods}

We measured the vertical distribution of total suspended sediment

$\left(\right.$ TSS $\left.=\mathrm{g} / \mathrm{m}^{3}\right)$, diatom abundance (frustules $\left./ \mathrm{m}^{3}\right)$ and diatom biomass $\left(\mathrm{g} . \mathrm{C} / \mathrm{m}^{3}\right.$ ) at $5-\mathrm{m}$ intervals to a depth of $40 \mathrm{~m}$ on monthly cruises from April 
to December 1975 at station 74-5 (Fig. 1), as described by Parker et al. $(1977 \mathrm{a}, \mathrm{b})$. Surface area integrals were calculated $(0-40 \mathrm{~m})$ and the data are presented on $\mathrm{m}^{2}$ basis. The concentration of soluble reactive silicon $\left(\mathrm{g} \underline{\mathrm{rSi}} / \mathrm{m}^{2}\right)$ and particulate amorphous silicon or diatom frustules ( $\mathrm{g}$ a Si $/ \mathrm{m}^{2}$ ) were measured throughout the water column at station $74-5$ by automated colorimetric analysis, as described by Conway et al. (1977). We determined particulate amorphous silicon as the percentage of the dry sediment collected in the epilimnion and in sediment traps that were suspended at $37 \mathrm{~m}$ and $60 \mathrm{~m}$ below the surface for $\sim 30$ day intervals from April to November at station 74-5, as described by Parker et al. (1977a). We measured the concentration of diatom frustules (frustules/g dry sediment) in 14 dated sediment cores $\left({ }^{210} \mathrm{~Pb}\right.$ technique, Robbins and Edgington, 1975), as described by Parker and Edgington (1976). We measured the concentrations of $\underline{a}$ Si and $\underline{\text { Si }}$ (in interstitial water) in a core collected at station 74-5, as described by Parker and Edgington (1976).

\section{Results and Discussion}

Maximal epilimnetic rSi concentration occurred in winter and early spring, but the level declined rapidly during the development of the spring diatom bloom in May and June (Fig. 2a). We observed a concomitant increase in asi concentration during the bloom. Peaks in diatom abundance and biomass also occurred in May and June (Fig. 2b). However, diatom abundance declined when $r$ Si levels declined below a limiting

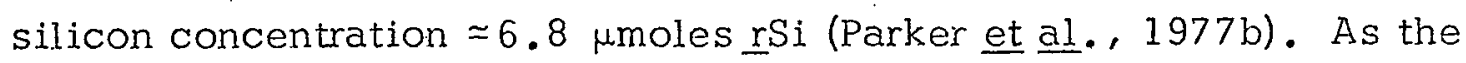
bloom waned, total silicon (rSi + a Si) in the epilimnion declined in 
response to zooplankton grazing and frustule settling. This resulted in minimal silicon levels in the epilimnion in early August.

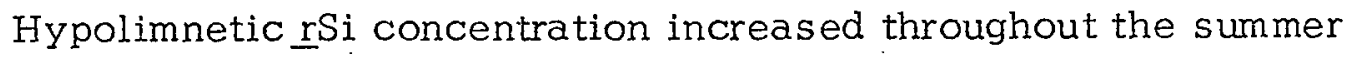
and by early fall advection transported sufficient $\underline{r} S i$ into the epilimnion to initiate the development of a fall diatom bloom. Maximal diatom abundance and biomass occurred in October and November. The aSi concentration increased slightly during the fall bloom, but it did not attain the concentration observed in spring since the diatom community consisted of smaller species that had less heavily silicified frustules. The fall diatom bloom waned in early winter, perhaps in response to reduced light intensities, but not because of reduced $\underline{\mathrm{S}} \mathrm{Si}$ level.' During

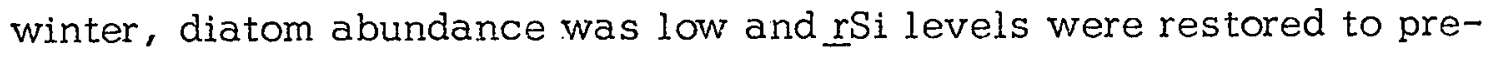
spring bloom levels. These observations demonstrate the seasonal cycle of diatom production and the strong relationship between diatom bloom sequencing and the availability of epilimnetic rsi resources.

The mechanisms responsible for the restoration of the $\underline{\mathrm{S}} \mathrm{Si}$ resources necessary for bloom development were evaluated by tracking the loss of diatom frustules and asi during settling of particulate material from the epilimnion to the bottom sediment. For comparative purposes, the concentration of frustules and a sediment.

A comparison of the percent a Si per unit of suspended sediment in the epilimnion, and per unit of sediment collected in the traps, showed that a progressive reduction in percent of a Si occurred during settling 
(Fig. 2c,d). The seasonal distribution of frustules per gram of dry sediment showed a similar reduction. The average loss of aSi and frustules during settling from the epilimnion into the traps and to the surface of the bottom sediment are shown in Table 1. These data suggest. that approximately $76-98 \%$ of the frustules are dissolved before they can be incorporated in the bottom sediment. Zooplankton grazing fractures the frustules and appears to strongly enhance the dissolution process (Ferrante and Parker, 1976). Frustule dissolution àppears to account for the major fraction of the increase in $\underline{r} \mathrm{Si}$ in the hypolimnetic water.

The concentration of diatom frustules per gram of dry sediment in the 14 sediment cores decreased by at least two orders of magnitude with depth in each core equivalent to $\simeq 80-100$ years B.P. (Fig. 3). In three cores the concentration of frustules diminished to undetectable levels at 150 years B.P. The vertical distribution of frustules and the concentration

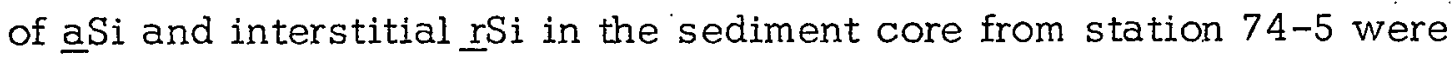
compared (Fig. 4). A rapid reduction in number of frustules and a Si during the first 10 years of burial in the sediment corresponds to an increasing concentration of $\underline{r}$ Si in the interstitial water. The maximum $\underline{r} S i$ concentration occurs at $\simeq 25-35$ years B.P. Below the maximum all three variables appear to decline at about the same rate. These data strongly suggest that frustules are dissolving within the sediment and that the sediment may

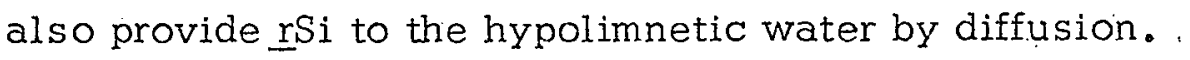

The importance of silicon recycling was estimated by comparing the annual silicon requirement for diatom production with the data on land drainage inputs of $\underline{\underline{S}} \mathrm{Si}$ and with the data on frustule decomposition. 
Based on the number of frustules produced per year and the average silicon content of frustules, as described by Parker and Edgington (1976), the annual silicon requirement is $\simeq 64 \mathrm{~g} \mathrm{Si} / \mathrm{m}^{2} \cdot \mathrm{yr}$. Based on a conversion of net annual diatom production, in units of carbon, to units of silicon (Parker et al., 1977a) a second estimate suggests that $\sim 53 \mathrm{~g} \mathrm{Si} / \mathrm{m}^{2}$. yr is required. The annual input of $\underline{r}$ Si from land drainage was estimated by Ayers (1970) and Upchurch (1972) as $9.35 \times 10^{7}$ and $9.82 \times 10^{7} \mathrm{~kg} \mathrm{Si} / \mathrm{yr}$, respectively. This represents $\sim 1.66 \mathrm{~g} \mathrm{Si} / \mathrm{m}^{2} \cdot \mathrm{yr}$ or $\sim 2.5$ to $3.0 \%$ of the annual silicon requirement for diatom production. The annual loss of silicon to the surficial sediment was estimated by converting the annual frustule deposition rate in the 14 sediment cores to units of silicon (Parker and Edgington, 1976). This calculation suggested an annual deposition of $\sim 1.33 \mathrm{~g} \mathrm{Si} / \mathrm{m}^{2} \cdot \mathrm{yr}$.

These observations suggest that the majority of the annual silicon requirement for diatom production is provided by dissolution of frustules

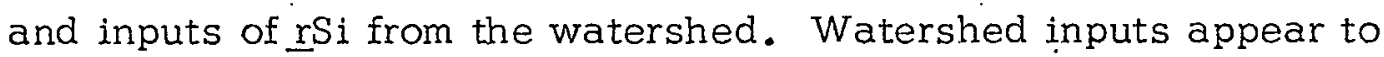
compensate for the loss of frustules to the sediment.

\section{Acknowledgements}

This work was supported by a grant from the U. S. Energy Research and Development Administration to the Radiological and Environmental Research Division at Argonne National Laboratory. We are grateful to the Division of Environmental Impact Studies at Argonne National Laboratory who provided support for the presentation of this manuscript. 


\section{References}

Ayers, J. C. 1970. Estimates of the radiological and chemical wastes to be released to the lake, $\mathrm{Cl}-\mathrm{C} 14$. In: J. C. Ayers (ed.), Lake Michigan environmental survey. Great Lakes Res. Div., Univ, Mich., Spec. Rep. 49.

Battarbee, R. W. 1972. Preliminary studies of Lough Neagh sediments. Part II. Diatom analyses from the uppermost sediment. Brit. Ecol. Soc. (in press).

Conway, H. L., J. I. Parker, E. M. Yaguchi, and D. L. Mellinger. 1977. Biological utilization and regeneration of silicon in Lake Michigan. J. Fish. Res. Board Can. 34: 537-544.

Duthie, H.C. and M. R. Sreenivasa. 1971. Evidence for the eutrophication of Lake Ontario from the sedimentary diatom succession. Proc. 14th Conf. Great Lakes Res., Int. Assoc. Great Lakes Res., p. $1-13$

Ferrante, J. G. and J. I. Parker. 1977. Transport of diatom frustules by copepod fecal pellets to the sediments of Lake Michigan. Limnol. Oceanogr. 22: $92-97$.

Frey, D. G. 1974. Paleolimnology. Mitt. Int. Ver. Limnol. 20: 95-123. Parker, J. I. and D. N. Edgington. 1976. Concentration of diatom frustules in Lake Michigan sediment cores. Limnol. Oceanogr. 21: $887-893$.

Parker, J. I., H. L. Conway, and E. M. Yaguchi. 1977a. Dissolution of diatom frustules and recycling of amorphous silicon in Lake Michigan. J. Fish. Res. Board Can. 34: 545-551. 


\section{Table Captions}

Table 1. Loss of diatom frustules during settling as indicated by the average concentration of diatom frustules and amorphous silicon: per gram of dry sediment in the epilimnion, sediment traps and surficial bottom sediment at station $74-5$. 


\begin{tabular}{|c|c|c|c|c|}
\hline Depth & $\begin{array}{c}\text { Average } \\
\text { frustules/g dry sed }\end{array}$ & $\begin{array}{c}\% \\
\text { Reduction }\end{array}$ & $\begin{array}{c}\text { Average } \\
\mathrm{g} \text { ab } \mathrm{S} / \mathrm{g} \text { dry sed }\end{array}$ & $\stackrel{\%}{\text { Reduction }}$ \\
\hline $0-40 m$ & $3.92 \times 10^{8}$ & 0 & 0.086 & 0 \\
\hline $37-m$ trap & $1.16 \times 10^{8}$ & 70 & 0.077 & 10 \\
\hline 60-m trap & $5.03 \times 10^{7}$ & 87 & 0.060 & 30. \\
\hline $\begin{array}{l}\text { Surficial } \\
\text { bottom } \\
\text { sediment } \\
(67 \mathrm{~m})\end{array}$ & $6.31 \times 10^{6}$ & 98 & 0.021 & 76 \\
\hline
\end{tabular}




\section{Figure Captions}

Figure 1. Location of Lake Michigan sampling stations.

Figure 2. Seasonal distribution of (a) the concentration of reactive and amorphous silicon, (b) diatom abundance and biomass, (c) total suspended sediment and the proportion contributed by amorphous silicon, and (d) the proportion of amorphous silicon in the material collected in sediment traps. (The $\mathrm{m}^{2}$ values are based on depth integrals from the surface to $40 \mathrm{~m}$.)

Figure 3. Vertical distribution of diatom frustules in 14 dated sediment cores (core depth as years Before Present).

Figure 4. Concentration gradients of soluble reactive silicon in the interstitial water, diatom frustules, and amorphous silicon from a sediment core collected at station $74-5$. 


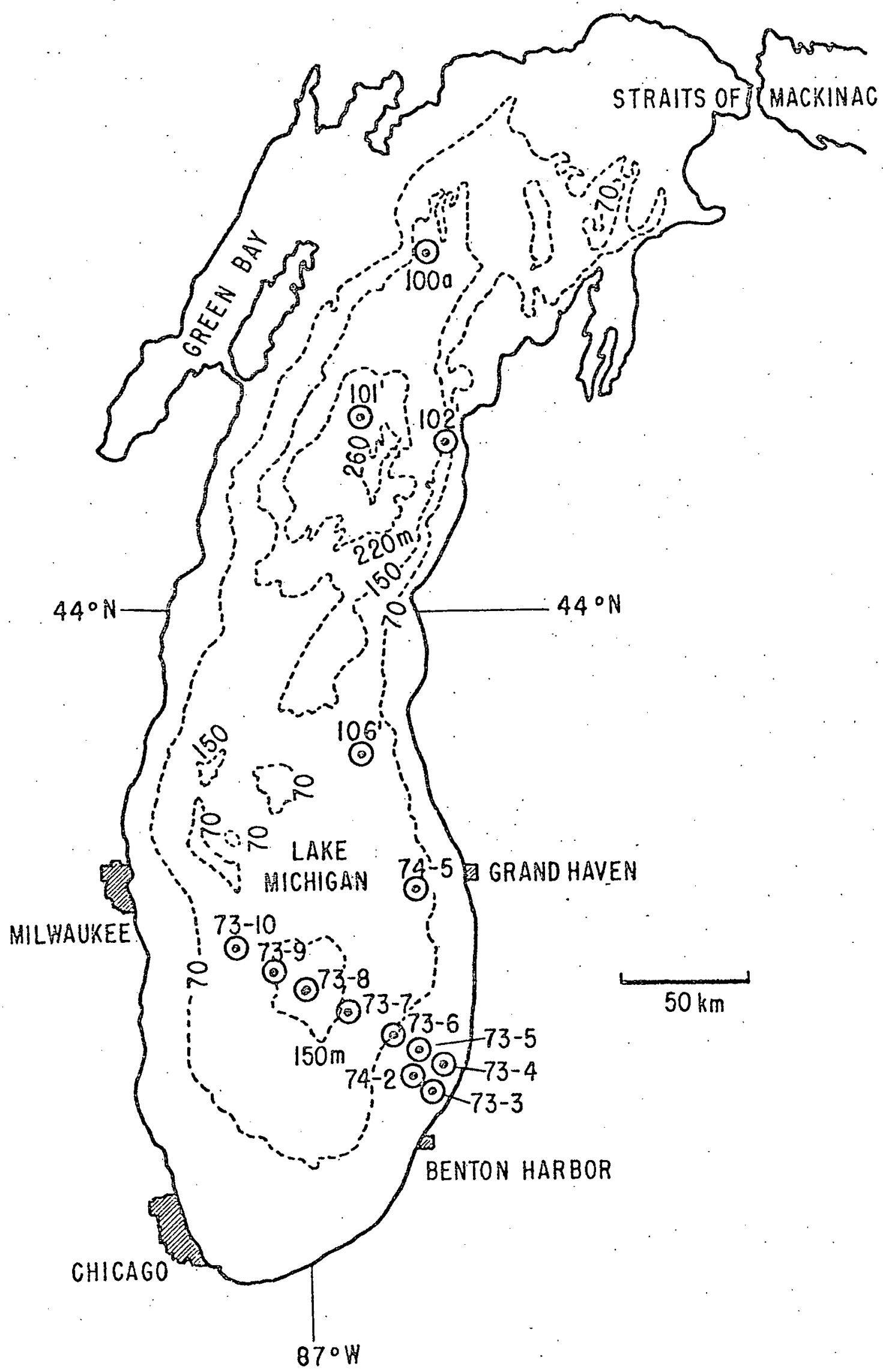




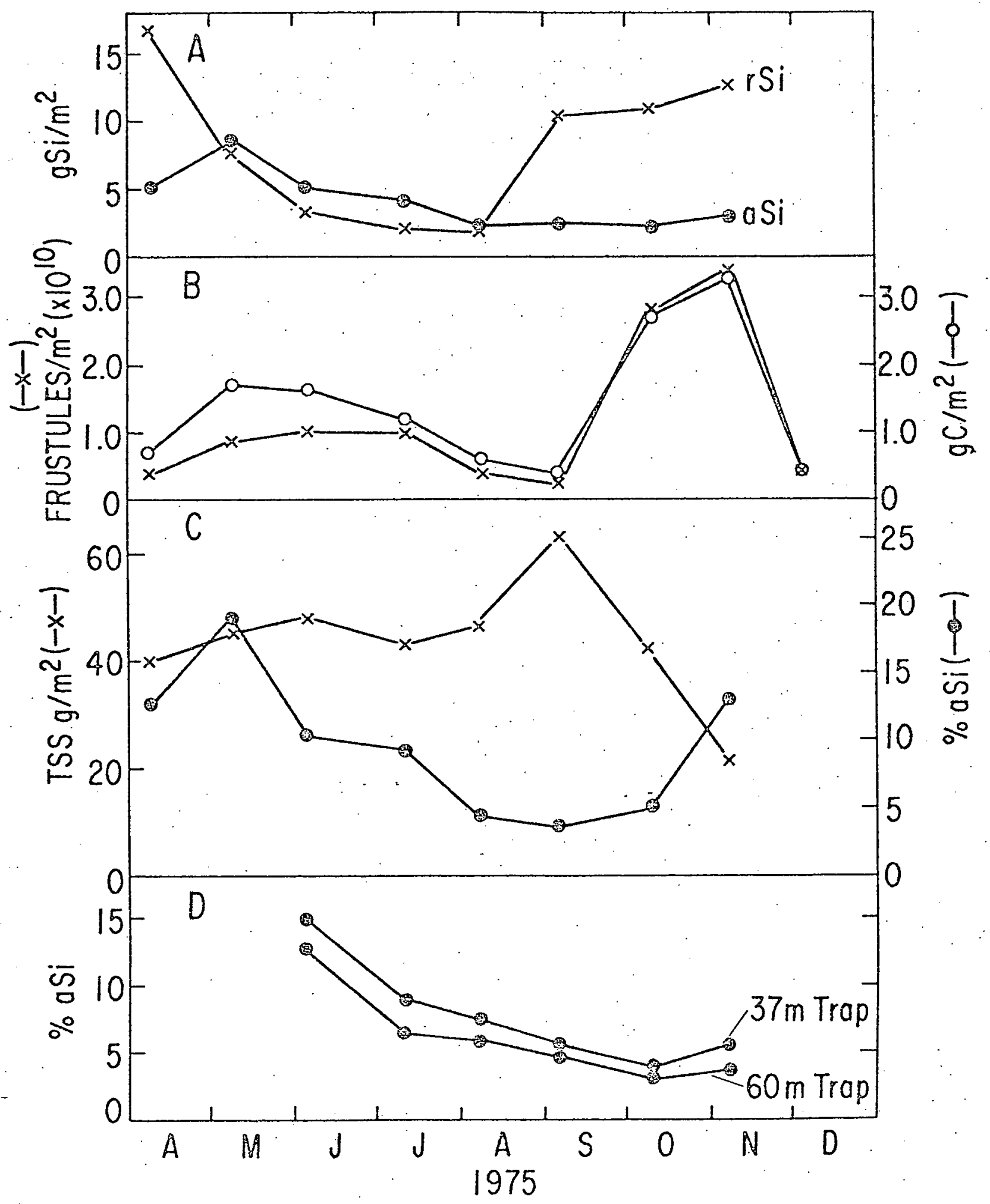


$L_{10}$ FRUSTULES/g DRY SEDIMENT

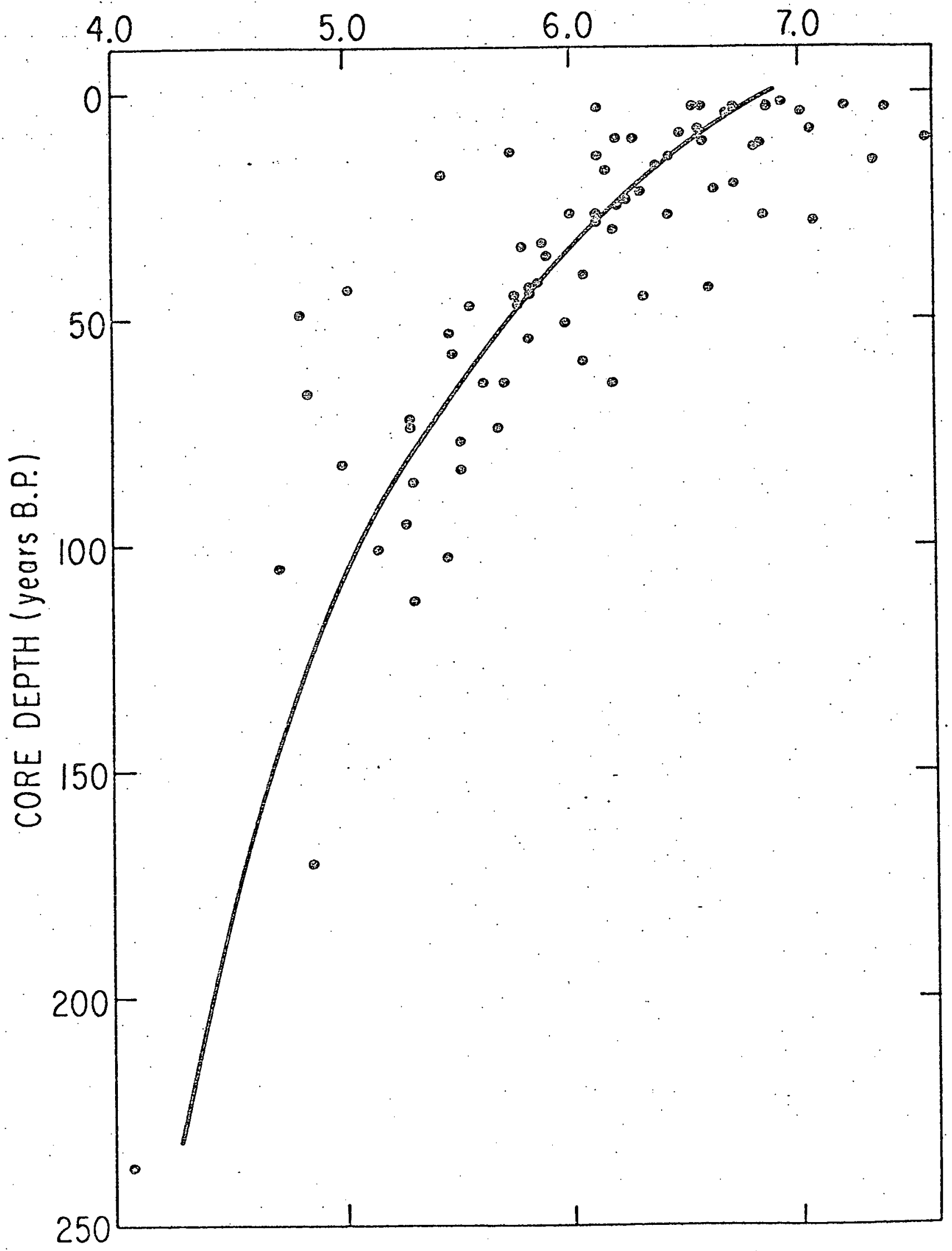




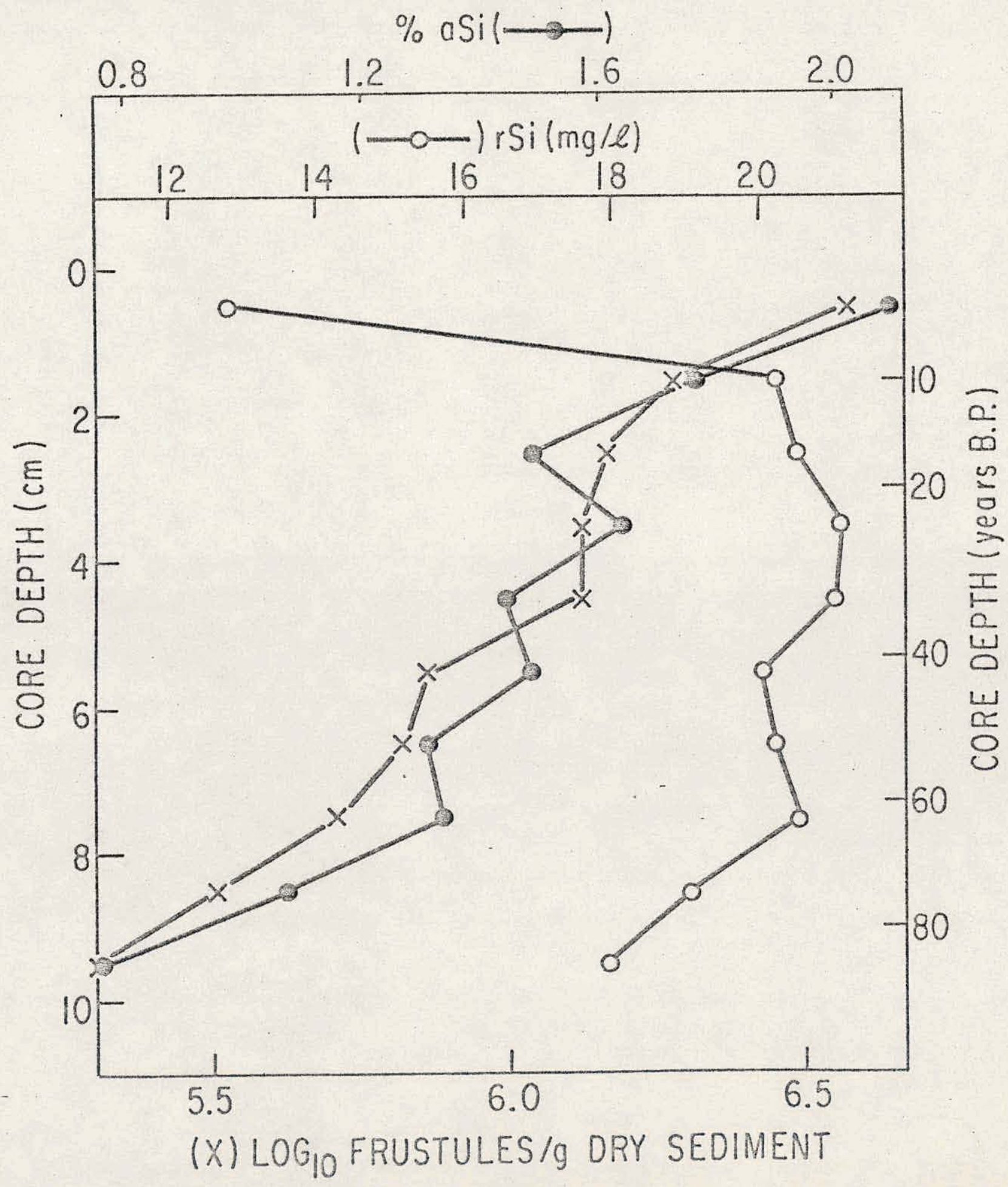

